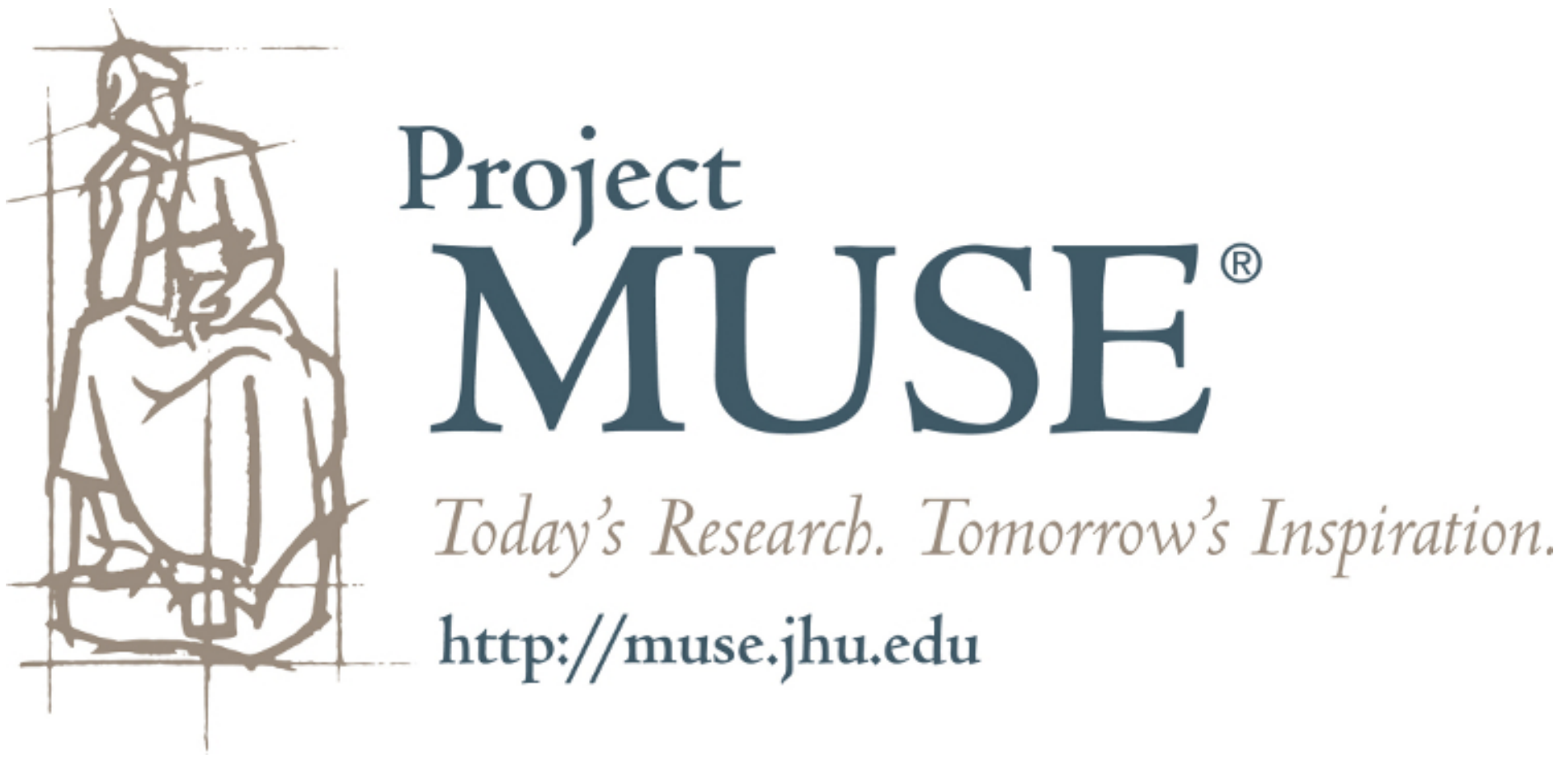




\section{The Search for Confessors at the Council of Nicaea}

\section{JAMES A. KELHOFFER}

Were confessors prominent and influential participants in the Council of Nicaea? Modern scholars have often thought so, but this article will explore the weak evidentiary basis for this claim. For the purpose of this inquiry, "confessors" (Lat.: confessores) are believers who suffered and were maimed in times of persecution, but not killed. This article examines the evidence for the presence and role of confessors at the Council of Nicaea. The term "confessor," however, did not have a fixed definition in the early church. In the broadest sense, a confessor acknowledged that he or she was Christian and was prepared to suffer in a time of persecution. Some confessors died for faith convictions, becoming martyrs, while others survived various sufferings, including torture and bodily mutilation. ${ }^{1}$

The question to be answered is whether the divergent claims of several ancient sources can support the view that confessor bishops exercised greater authority at the Council of Nicaea because of the persecutions they had borne. This article's "search for confessors," therefore, is to determine both the presence and the authority of confessors at the Council by examining the citations offered to support the view that their influence was substantial in the formulation and acceptance of the creed. It will be argued that, although there is no reason to question that some confessors were present at this Council, the harmonizing approach of Timothy Barnes, among other scholars, to the ancient witnesses spawns both historical and literary misinterpretations.

The main late ancient Christian author to be examined is Theodoret of Cyrrhus (c. 387-c. 457), who, roughly a century after this Council, claims that an "assembly of martyrs" was gathered at Nicaea (H. e. 1.7.6). The specific issues

My thanks to Katharina Bracht, Peter W. Martens, Frederick G. McLeod, S.J., Roger Pearse, and Clare K. Rothschild, for helpful suggestions on this study.

1. See further Bernhard Kötting, "Die Stellung des Konfessors in der alten Kirche," JbAC 19 (1976): 7-23; Donald C. Nevile, "The Role of 'Confessor' in the Ministry of the Early Church," Consensus 20 (1994): 29-37. Cf. Louis-Sébastien Le Nain de Tillemont, The History of the Arians, and of the Council of Nice[a], 2 vols., trans. Thomas Deacon (London: G. Strahan, 1732), 1:59 (on Marianus [discussed below]), 1:131-32 (on Eustathius of Antioch), 1:195 (on Martin, who was given the title of confessor in Illyricum), 1:197-98 (on Hilary of Poitiers). 
of this Council (most notably, the Son as being from the "ousia" of the Father, or homoousios with the Father) do not directly bear upon the present inquiry. What is of interest is Theodoret's depiction of bishops who had suffered under the relatively recent persecutions in such a contentious gathering to define the Son's ontological relationship to the Father. ${ }^{2}$

Accepting Theodoret's depiction as a reliable account of confessors at this Council, Timothy Barnes writes about the confessors there: "Prestige did not depend mainly on a bishop's see nor on his subtlety in debate. Confessors, especially those whose missing eyes and maimed ankles manifested proof of their steadfastness during persecution, enjoyed enormous authority." ${ }^{3}$ In a footnote, Barnes indicates that he bases this inference on the following five ancient witnesses, which this article examines: Rufinus, H. e. 10.4, 12; Socrates, H. e. 1.11.1ff.; Sozomen, H. e. 1.10, 23; Theodoret, H. e. 1.7.6, 2.26.6; and Gelasius of Cyzicus, H. e. 2.9.4 Other scholars who come to a similar conclusion about the prominence of maimed confessors at Nicaea include Ramsay MacMullen as well as Averil Cameron and Stuart G. Hall. ${ }^{5}$ Several other influential accounts of Nicaea and of early Christian confessors do not address the issue. ${ }^{6}$

2. In regard to an analogous conflict in Egypt, see W. H. C. Frend, Martyrdom and Persecution in the Early Church: A Study of a Conflict from the Maccabees to Donatus (Oxford: Blackwell, 1965), 539-41, on the (non-“orthodox") Melitian bishops and monks, who claimed "to be "the Church of the Martyrs" (540). See also R. P. C. Hanson, "The Council of Nicaea," in his The Search for the Christian Doctrine of God: The Arian Controversy 318-381 (Edinburgh: T. \& T. Clark, 1988), 174-75.

3. Timothy D. Barnes, Constantine and Eusebius (Cambridge, MA: Harvard University, 1981), 214-15, quoted at 214.

4. Barnes, Constantine and Eusebius, 379 n. 52 (referring to the above citation of p. 214).

5. Ramsay MacMullen, Constantine (New York: Dial, 1969), 172-73 at 172, infers that the confessors held prominence at Nicaea, in contrast to the majority of "backbenchers," who held less important seats. MacMullen holds that among the bishops present at Nicaea "were some of Christianity's heroes-Paphnutius, whose blinded eye socket he [Constantine] kissed in veneration, James of Antioch, whose piety could raise the dead, Paul of Neocaesarea with his burned hands, all glorious and reverend survivors of the persecutions; with them [were] the backbenchers, forming the great majority of the Council and representing the average-sized and smaller sees." Likewise, in their commentary on Eusebius's Life of Constantine, Averil Cameron and Stuart G. Hall, Eusebius, Life of Constantine: Introduction, Translation, and Commentary (New York: Oxford University Press, 1999), 263, cite Barnes in support of this point; yet as noted below, Eusebius actually does not portray any confessors at Nicaea.

6. For example, Lewis Ayres, Nicaea and Its Legacy: An Approach to FourthCentury Trinitarian Theology (New York: Oxford University Press, 2004), esp. 88-92; Aloys Grillmeier, S.J., Christ in Christian Tradition, Vol. 1: From the Apostolic Age to Chalcedon [451], trans. John Bowden (Atlanta, GA: John Knox, 1975), 249-73, esp. 252-64 (on the role of Constantine at the Council); Hanson, Search for the Christian Doctrine of God; Peter L'Huillier, The Church of the Ancient Councils (Crestwood, NY: St. Vladimir's Seminary, 1996); Kötting, "Stellung des Konfessors"; Nevile, "Role of 'Confessor'"; Norman P. Tanner, ed., Decrees of the Ecumenical Councils (Lon- 
A germ of this idea could perhaps be traced to Louis-Sébastien Le Nain de Tillemont (d. 1698), who, over three centuries ago, claimed that a Christian named Marianus "had the office of imperial notary (or secretary of state, which was very considerable at the time)," and that Marianus had "been a Confessor for Jesus Christ during the persecution." Tillemont's assertion stems from a conflation of Sozomen and Eusebius: Sozomen describes Marianus as "imperial notary" at the Council, and Eusebius of Caesarea is said to mention Marianus as a confessor. ${ }^{8}$ Significantly, neither Sozomen nor Eusebius is said to highlight Marianus's importance as a confessor and that Marianus was present at the Council of Nicaea; nor does Tillemont himself make this claim. Tillemont also voices some hesitation about identifying Marianus as a confessor-albeit for a dogmatic, rather than any plausible historiographic, reason. ${ }^{9}$ In any case, the Marianus whom Tillemont mentions is to be distinguished from Paul of Neocaesarea and Paphnutius of Egypt, confessors mentioned in other witnesses that this article examines.

This article argues that not all of the ancient sources to which Barnes refers claim, let alone plausibly support, his conclusion that "[c]onfessors . . . enjoyed enormous authority" at Nicaea. ${ }^{10}$ We examine the-at times, divergent-claims of these authors and their depictions of the honor accorded to those who had suffered. The ancient author who comes closest to Barnes's generalization is Theodoret, with whom we shall begin. Like the other patristic witnesses to which Barnes refers, Theodoret wrote in the fifth century, roughly a century after Nicaea.

As is well known, the task of reconstructing historically the situation and debates at Nicaea is quite complicated, if not, at times, impossible. Norman P. Tanner observes that during the deliberations at Nicaea "probably no official account of the Council was ever written down by secretaries." 11 Moreover, the only two eyewitness reports of the proceedings of the Council come from Athanasius of

don: Sheed \& Ward/Washington, DC: Georgetown University Press, 1990 [1972]); Frances M. Young with Andrew Teal, From Nicaea to Chalcedon: A Guide to the Literature and Its Background, 2nd ed. (Grand Rapids, MI: Baker Academic, 2010).

7. Tillemont, History of the Arians, 1:59.

8. See Sozomen, H. e. 2.26 (= NPNF $\left.{ }^{2} 2: 276\right)$. I have not been able to verify Tillemont's reference to Eusebius (listed in History of the Arians, 1:59 note $\theta$ as "n. p. 247. 2. c.").

9. Tillemont's hesitation about the identity of Marianus is evident in the possibility that, according to Athanasius, "Marianus the notary" embraced an Arian Christology: "[Marianus] seems to have perform[e]d the function of a servant of the Arians, rather than a Confessor of Jesus Christ" (History of the Arians, 1:59). For Tillemont, a true confessor would have embraced the "orthodox" formulation of Nicaea. Although Tillemont's argument is an obvious non sequitur, it is not germane to this article. Tillemont, History of the Arians, 1:59 note $\theta$, lists his reference to Athanasius, De decretis synodis as "p. 904. b.," a reference that I have been unable to verify.

10. Barnes, Constantine and Eusebius, 214.

11. Tanner, Decrees of the Ecumenical Councils, 1:2. See also Hanson, Search for the Christian Doctrine of God, 157-59. 
Alexandria and Eusebius of Caesarea, who are silent about the place of confessors at Nicaea. ${ }^{12}$ When examining Theodoret and other fifth-century accounts of this Council and its maimed attendees, we consider both the depictions of one or more confessors' standing and the apparent growth of these traditions over time.

\section{THEODORET OF CYRRHUS ON}

\section{“AN ASSEMBLY OF MARTYRS” AT NICAEA}

In his fifth-century Church History, Theodoret writes the following about the bishops gathered at Nicaea:

Three hundred and eighteen bishops ${ }^{13}$ were assembled. . . . At this period many individuals were richly endowed with apostolic gifts; and many, like the divine

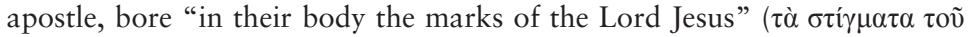
кupíov 'Inбoṽ). ${ }^{14}$. . . Paul of Neocaesarea . . . had suffered from the frantic rage

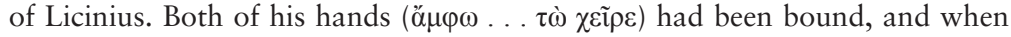
a red-hot iron was applied to them, the locomotive nerves of the joints were contracted and rendered dead. Some had had the right eye dug out, while others had had the right forearm cut off. One of them was Paphnutius the Egyptian. In

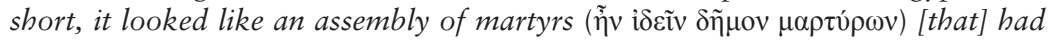
been gathered together. ${ }^{15}$

Several aspects of Theodoret's claims merit particular attention. First, "many individuals," who during the recent persecutions had suffered torture, including dismemberment, were among the bishops gathered at Nicaea. Second, Paul of Neocaesarea had been maimed under Licinius (H. e. 1.7.5). In Theodoret's depiction, the identity of which bishops had been disfigured or maimed would have been obvious to those in attendance at Nicaea. Third, Theodoret mentions only in passing "Paphnutius the Egyptian," about whom Rufinus, Socrates, and Sozomen have somewhat more to say. ${ }^{16}$ Fourth, in describing the convocation at Nicaea as "an assembly of martyrs" ( $\delta \tilde{\eta} \mu o v \mu \alpha \rho \tau \dot{\rho} \rho \omega v)$, Theodoret highlights

12. See further on this point below.

13. As in H. e. 1.7.3 (above), Theodoret offers the same number of bishops (318) at H. e. 1.11.1 (= H. e. 1.10.1 in NPNF $3: 48-49)$. By contrast, Eusebius of Caesarea, who was present at the Council of Nicaea, claimed that over 250 bishops were present (V. C. 3.1, cited below). See further Tanner, Decrees of the Ecumenical Councils, $1: 1$, who notes that the number of 318 bishops present at Nicaea originally stems from Hilary of Poitiers (c. 300-c. 368) and afterward "became traditional." The number 318 may also be based on Gen 14.14 (the number of Abraham's servants). See further Cameron and Hall, Life of Constantine, 263-64, and L'Huillier, Church of the Ancient Councils, 18-19.

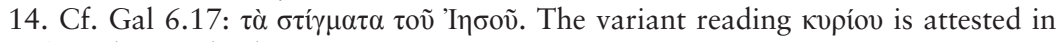
$\mathrm{C}^{3}, \mathrm{D}^{2}$, and several other witnesses.

15. Theodoret, H. e. 1.7.3, 5-6 (ed. Jean Bouffartigue et al., Théodoret de Cyr. Histoire ecclésiastique, SC 501 [Paris: Éditions du Cerf, 2006-9], 200-202; trans. $\mathrm{NPNF}^{2}$ 3:43 [= H. e. 1.6.3, 5-6], modified for accuracy). Cf. Theodoret, H. e. 2.33.4 (= H. e. 2.28 .4 in $\left.\mathrm{NPNF}^{2} 3: 93\right)$.

16. See further below on these witnesses to Paphnutius of Egypt. 
the past suffering of (many of) those present and thereby links their suffering to the Council's authority in matters of dogma.

Elsewhere in his Church History, Theodoret states that even the emperor Constantine wanted a blessing from confessors at Nicaea: "Observing that some [of them] had had the right eye dug out, ${ }^{17}$ and learning that this mutilation had been undergone for the sake of religion, [Constantine] placed his lips upon the wounds, believing that from there he would extract a blessing by means of a kiss." 18 Theodoret of Cyrrhus's fifth-century testimony portrays great respect for maimed bishops at Nicaea. Because the confessors had been steadfast amidst such acute forms of oppression, this Council's doctrinal formulations and other decisions have greater weight. The stature of these confessors is also attested by their ability to grant a blessing to the emperor.

\section{RUFINUS AND PSEUDO-GELASIUS ON THE CONFESSOR PAPHNUTIUS OF EGYPT AT NICAEA}

As mentioned above (cf. Theodoret, H. e. 1.7.6), another fifth-century author, Rufinus of Aquileia (345-411), mentions a particular confessor present at Nicaea, Paphnutius of Egypt. Rufinus offers three corroborations of Paphnutius's standing: he was maimed, he performed miracles, and Constantine honored his suffering. Rufinus first names Paphnutius as among those present at Nicaea and as one of the confessors who had suffered under the emperor Maximinus: "There was also at the Council Paphnutius, a man of God [and] a bishop from Egypt, a confessor among those (confessor ex illis) whom Maximinus, after gouging out [their] right eyes and cutting off [their] left [leg at the] knee (sinistro poplite), had condemned to the mines." 19 Lactantius describes the policy of Maximinus, who, after succeeding Galerius in 311, had reversed Galerius's policy of toleration and "ordered [Christians] to be maimed." ${ }^{20}$ In Rufinus's account, the combination of being condemned to hard labor in the dark mines with use of only one eye and one foot was an extreme and ongoing form of torture, which, in turn, attests to Paphnutius's longsuffering for his Christian faith.

Rufinus also highlights Paphnutius as a miracle worker, as the first apostles

17. Cf. Theodoret, H. e. 1.7.5, cited above.

18. Theodoret, H. e. 1.11.1 (SC 501:234; trans. NPNF² 3:48 [= H. e. 1.10.1], modified for accuracy.

19. Rufinus, H. e. 10.4 (ed. Theodor Mommsen, Eduard Schwartz, and Friedhelm Winkelmann, Eusebius Werke 2.2: Die Kirchengeschichte, GCS n. s. 6, 2 vols. [Berlin: Akademie Verlag, 1999], 2:963; my trans.).

20. Lact. Mort. 36.3, 6-7 (ed. and trans. J. L. Creed, De mortibus persecutorum, Oxford Early Christian Texts [Oxford: Clarendon, 1984], 54-55): "Firstly, [Maximinus] annulled the tolerance which had been accorded to the Christians in the name of all the emperors. ... While professing clemency as far as appearances went, he forbade the servants of God to be killed, but ordered them to be maimed (debilitari iussit). Thus confessors had their eyes gouged out, their hands cut off, their feet amputated, their noses or ears severed." Cf. Eus. M. P. 8.1. 
were. ${ }^{21}$ Reminiscent of Theodoret's general claim about Constantine and kissing the eye sockets of certain confessors, Rufinus calls attention to Paphnutius's missing eye, which the emperor Constantine would kiss:

Constantine held [Paphnutius] in such veneration and affection (in tanta veneratione et affectu) that he would frequently (saepius) call him into the palace, embrace ${ }^{22}$ [him], and caress with quite eager kisses (avidioribus osculis) the eye, which had been gouged out at [the time of] his confession of faith. ${ }^{23}$

For Rufinus, Paphnutius clearly enjoyed prominent standing among the faithful, including the emperor.

Additionally, an anonymous Church History, traditionally attributed to Gelasius of Cyzicus, ${ }^{24}$ offers a witness to Paphnutius that is strikingly similar to that of Rufinus. ${ }^{25}$ This Church History offers a (derivative and secondary) late-fifth century account of the acts and speeches of the Council of Nicaea. ${ }^{26}$ In the same order as Rufinus and with only minor editorial elaborations, Ps.-Gelasius mentions Paphnutius's maiming under the emperor Maximinus (H. e. 2.9.1) as well as his miracles like those of the first apostles and his eye socket that the emperor Constantine would kiss (H. e. 2.9.2). As C. H. Turner argued over a century ago, Ps.-Gelasius's depiction of Paphnutius is wholly derived from Rufinus. ${ }^{27}$ Therefore, Ps.-Gelasius has no value independent of Rufinus as a witness to

21. Rufinus, H. e. 10.4 (GCS n. s. 6.2:963; trans. Philip Amidon, The Church History of Rufinus of Aquileia, Books 10 and 11 [Oxford: Oxford University Press, 1997], 11-12): "But there was in him such a grace of miracles that signs were worked through him no less than through the apostles of old. For he put demons to flight with a mere word and cured the sick by prayer alone. He is also said to have returned sight to the blind and given back soundness of body to the crippled."

22. I infer that GCS n. s. 6.2:963, intended complecteretur and that conplecteretur is a typo.

23. Rufinus, H. e. 10.4 (GCS n. s. 6.2:963; my trans.).

24. Günther Christian Hansen, ed., Anonyme Kirchengeschichte (Gelasius Cyzicenus, CPG 6034), GCS n. s. 9 (Berlin: Walter de Gruyter, 2002), ix-xii, notes that the attribution to Gelasius of Cyzicus is based on a misunderstanding and that there is actually no evidence that a person by this name ever existed.

25. Ps.-Gelasius, H. e. 2.9 (GCS n. s. 9:43-44). Cf. Rufinus, H. e. 10.4.

26. Hansen, Anonyme Kirchengeschichte, xli-xlviii, observes that the anonymous author of this Church History claims to have been in Bithynia in the year 475-476 and that this author made use of earlier church histories in his work, including those of Eusebius, Theodoret, Rufinus, and Socrates. Thus, a late fifth-century date for this work is likely. As mentioned above, "Gelasius of Cyzicus, Hist. eccl. 2.9" is one of five late ancient Christian authors whom Timothy Barnes (Constantine and Eusebius, 214 and 379 n. 52) lists in support of his conclusion that "[c]onfessors ... enjoyed enormous authority" at Nicaea.

27. Turner, "On Gelasius of Cyzicus," JTS 1 (1899): 125: “[C]onsiderable portions of Gelasius are simply an amplified translation into Greek of Rufinus' Ecclesiastical History. Indeed, the whole of the narrative of Rufinus that deals with the Council ... is incorporated directly into Gelasius' second book: . . Rufinus x 4 = Gel. ii 9.” 
Paphnutius at Nicaea. Nonetheless, the perpetuation of Rufinus's (Latin) depiction in this anonymous Greek work could well have made a broader audience aware of Paphnutius's suffering and recognition, beginning in the late fifth century.

Historiographically, one could apply a harmonizing principle to the witnesses of Theodoret and Rufinus (and Ps.-Gelasius), construing each author as reliable for his particular details about one or more confessors at Nicaea. However, three observations about these authors' particular depictions call for caution. First, the only exact correspondence between Theodoret and Rufinus is the unremarkable assertion that Paphnutius of Egypt was a confessor and was present at the Council. Second, Theodoret (H. e. 1.7) makes a generalization about any number of unnamed confessors at Nicaea; he highlights the particular example of Paul of Neocaesarea's maimed hands but mentions Paphnutius of Egypt only in passing. Rufinus writes of only one confessor at Nicaea, namely Paphnutius. Rufinus does not state (or deny) that, in addition to Paphnutius, other confessors were present at the Council. Third, Theodoret makes another generalization about Constantine kissing the confessors' wounds, but Rufinus identifies only a single confessor as receiving this honor, namely Paphnutius. Therefore, Rufinus's testimony may be said to complement certain aspects of Theodoret's (and vice-versa), but neither author corroborates the other's particular claims. Furthermore, the even later and derivative witness of Ps-Gelasius offers no independent confirmation of Rufinus's testimony, let alone of Theodoret's.

\section{THE WITNESSES OF SOCRATES AND SOZOMEN}

Two other fifth-century church historians, Socrates and Sozomen, describe Paphnutius the confessor but do not highlight his presence, let alone any special standing accorded to him or any other confessor, at the Council of Nicaea. Like Rufinus, Socrates (c. 379-c. 440) calls attention to the honor that Constantine showed to this confessor:

Paphnutius was bishop of one of the cities in Upper Thebes: he was a man so devoted to God ( $\theta \varepsilon \circ \varphi \imath \lambda \eta \dot{\zeta})$ that wondrous signs were done by him. In the time of the persecution he had had an eye cut out. The emperor honored this man exceedingly, and was in the habit of sending for him to the palace and of kissing the place where the eye had been dug out. So great was the reverence ( $\varepsilon \dot{\jmath} \lambda \dot{\alpha} \beta \varepsilon 1 \alpha)$ of the emperor Constantine. ${ }^{28}$

In Socrates' account, the emperor demonstrates his $\varepsilon \dot{\lambda} \lambda \alpha \dot{\beta} \varepsilon 1 \alpha$ by the honor he showed to this confessor. In other words, the corroboration that Socrates highlights belongs to Constantine, not to this (or any other) confessor.

Like Rufinus and Socrates, Sozomen (c. 400-c. 450) mentions Paphnutius as a confessor. As in Socrates' account, Sozomen never states that this, or any other,

28. Socrates, H. e. 1.11.1-2 (ed. Pierre Périchon et al., Socrate de Constantinople. Histoire ecclésiastique, SC 477 [Paris: Éditions du Cerf, 2004-7], 142-44; trans. Edward Walford, The Ecclesiastical History of Socrates, Surnamed Scholasticus, or the Advocate [London: H. Bohn, 1853], 39-40, modified). 
confessor attended Nicaea. ${ }^{29}$ Sozomen states that Paphnutius and other confessors "adorned [or: exalted/magnified] the churches," 30 but does not report that they "adorned" the Council of Nicaea. Thus, the accounts of Socrates and Sozomen do not confirm the claims of either Theodoret or Rufinus. Furthermore, it is odd that Timothy Barnes cites Socrates and Sozomen as supporting the claim that "[c]onfessors . . enjoyed enormous authority" at Nicaea. ${ }^{31}$ Socrates and Sozomen do not report that confessors played any role at all at Nicaea.

\section{THE SILENCE OF THE NICENE CANONS, ATHANASIUS, AND EUSEBIUS}

In addition to the divergent depictions of the aforementioned fifth-century witnesses to Nicaea, the silence of fourth-century witnesses about the place of confessors at this Council is noteworthy. For example, several of the canons of Nicaea discuss the issue of people who had lapsed during persecution, but offer no special recognition to confessors who had remained steadfast during persecution. ${ }^{32}$ Moreover, the Letter of the Synod in Nicaea to the Egyptians is also silent about confessors at this Council. ${ }^{33}$

As mentioned above, only two people who wrote about this Council were actually present for its deliberations-Athanasius of Alexandria and Eusebius of Caesarea. Eusebius resisted deeming the Son as homoousios with the Father. Regarding Christology, the accounts of Eusebius about the Council of Nicaea (which embraced the homoousios formulation in condemning Arianism) differ markedly from those of Athanasius and are famously not without bias. ${ }^{34}$ For our purposes, the contrasting tendencies of these two witnesses are not pertinent, since neither Athanasius nor Eusebius mentions confessors at this Council. For example, Athanasius is silent about the confessors in his works De decretis synodis and Epistula ad episcopos Africae. Likewise, whereas Eusebius writes extensively about martyrs and confessors in his Martyrs of Palestine, he never places any confessors at the Council of Nicaea. ${ }^{35}$ Furthermore, in 326 Eusebius wrote a letter to offer an explanation of this Council, as Edward R. Hardy notes, to his "own church . . . immediately after or perhaps even during the sessions

29. Sozomen, H. e. 1.10.1-2 (ed. Guy Sabbah et al., Sozomène. Histoire ecclésiastique, SC 306 [Paris: Éditions du Cerf, 1983-2008], 154-56; trans. NPNF² 2:246).

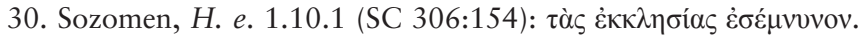

31. See above on Barnes, Constantine and Eusebius, 214 and 379 n. 52.

32. See Canons 8, 10,11, 14 (cf. 12), in Tanner, Decrees of the Ecumenical Councils, 1:9-13. In addition, Theodore of Mopsuestia (c. 350-428) treats the dogmatic import of the Nicene Creed (or a version of this) in the first ten homilies of his Catechetical Homilies, but he, too, says nothing about those who attended other than that 318 bishops were present.

33. The Letter of the Synod in Nicaea to the Egyptians, in Tanner, Decrees of the Ecumenical Councils, 1:16-19.

34. See, e.g., Young, From Nicaea to Chalcedon, 6-8, 16-21.

35. Eusebius, M. P. 3.3[S], 8.1-13, 10.1, 11.4-5, 13.1-5, 13.6[S], 13.9-10; cf. Lawlor and Oulton, Ecclesiastical History and the Martyrs of Palestine, 2:328. 
of the Council." ${ }^{36}$ Eusebius's Letter to the Church of Caesarea also says nothing about a prominent place given to confessors.

In his Life of Constantine, moreover, Eusebius also makes no reference to the prominence of maimed confessors at Nicaea. ${ }^{37} \mathrm{He}$ mentions only-and somewhat obliquely - that some who attended this Council "were outstanding . . . for their severity of life and patient endurance": ${ }^{38}$

Among the ministers of God [at Nicaea] some were outstanding ([or: "prominent"] $\delta 1 \varepsilon \dot{\varepsilon} \rho \varepsilon \pi \mathrm{ov})$ for the word of wisdom, others for their severity of life and patient

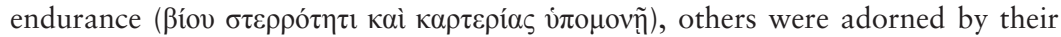
moderation. Some among them were honored for their length of years, others shone with youth and the height of [their] strength, some had just reached the road of [priestly] ministry. ${ }^{39}$

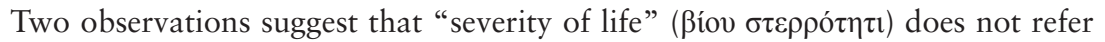

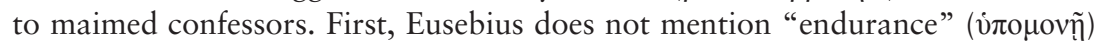

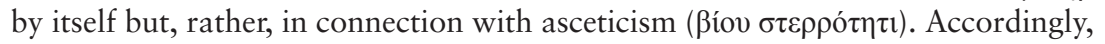

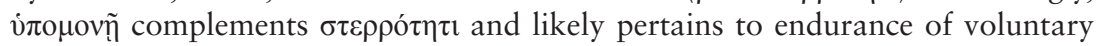
ascetic practices rather than to withstanding oppression from outsiders. Second, asceticism and endurance (however construed) appear in a series of honored qualities that attendees at Nicaea possessed; Eusebius does not present asceticism and endurance as more prominent than wisdom, moderation, age, or youth.

Given these considerations, it is therefore curious that, in their commentary on Eusebius's Life of Constantine, Averil Cameron and Stuart Hall cite Timothy Barnes about the prominence of confessors at Nicaea. ${ }^{40}$ In effect, Cameron and Hall interpolate the later (fifth-century) witness of Theodoret (H. e. 1.7, discussed above) for a point not present in Eusebius's eyewitness account. Since neither Eusebius nor Athanasius could be cited as evidence that confessors were present, let alone honored, at Nicaea, these eyewitnesses offer no support for Cameron and Hall's use of Barnes on this point

Furthermore, Eusebius's great esteem for the martyrs and their value as corroboration for his rhetoric of history are well known. ${ }^{41}$ At the very least, it is odd that an attendee of the Council, who elsewhere writes so much about the

36. Edward R. Hardy, ed., Christology of the Later Fathers (Philadelphia, PA: Westminster, 1954), 335. An ET of Eusebius's Letter to the Church of Caesarea may be found in Hardy, Christology, 336-40. See further Ayres, Nicaea and Its Legacy, 90-91; Hanson, Search for the Christian Doctrine of God, 163-64.

37. Eusebius, V. C. 3.[1]7-9 (ed. Horst Schneider and Bruno Bleckmann, Eusebius von Caesarea: Über das Leben Konstantins, Fontes Christiani 83 [Turnhout: Brepols, 2007], 318-20).

38. Eusebius, V. C. 3.[1]9 (Schneider and Bleckmann 320).

39. Eusebius, V. C. 3.[1]9 (Schneider and Bleckmann 320; trans. Cameron and Hall, Eusebius, Life of Constantine, 124, modified).

40. Cameron and Hall, Eusebius, Life of Constantine, 263, following Barnes, Constantine and Eusebius, 214 (cited above) on this point.

41. See further Robert M. Grant, Eusebius as Church Historian (Oxford: Clarendon, 1980), 114-25; Young, From Nicaea to Chalcedon, 13-14. 
place of Christian martyrs in salvation history, would be silent about the confessors-that is, if any confessors were accorded special honor at Nicaea. Along with Socrates and Sozomen, then, Athanasius and Eusebius lend no credence to the witnesses of Theodoret and Rufinus about confessors at Nicaea. The silence of Athanasius and Eusebius, as well as Socrates and Sozomen, call for caution when assessing the reliability of Theodoret's fifth-century depiction of special honor accorded to confessors at this Council.

\section{CONCLUSION}

This article examines the five late ancient Christian authors, whom Timothy Barnes presents in support of the inference that "[c]onfessors . . . enjoyed enormous authority" at the Council of Nicaea. ${ }^{42}$ Barnes's claim is partially supported by only one witness, namely Theodoret. Rufinus (and Ps.-Gelasius) neither confirms nor denies Barnes's claim. Moreover, two of the ancient witnesses whom Barnes cites (Socrates and Sozomen) do not even state that confessors were present, let alone accorded "enormous authority," at Nicaea. These observations do not cast doubt upon whether some confessors, such as Paul of Neocaesarea and Paphnutius the Egyptian, were present at Nicaea. They do, however, question Barnes's credulous interpretation of Theodoret, H. e. 1.7 and harmonizing approach to other witnesses to support that "[c]onfessors . . . enjoyed enormous authority" at Nicaea. One may likewise question Cameron and Hall's use of Theodoret's later account to support a claim about confessors at Nicaea that is absent in Eusebius's eyewitness account. ${ }^{43}$

One must, of course, recognize that a critical, historical examination can achieve only probability. Athanasius, Eusebius, and other early witnesses may not have spoken about the presence of confessors because this did not fit in with their overall or specific purposes in writing. Nevertheless, the available evidence does not substantiate the view of Barnes, MacMullen, and Cameron and Hall that the confessors' impact was substantial: although this assessment may be correct, there is no corroborating proof for it, and it is therefore questionable. The possibility must be granted that Barnes and other scholars may be right, but the preponderance of the few citations available to us points in the direction that these scholars' viewpoint cannot be proven as even probable.

On a literary level, it is indeed interesting that Theodoret attests to the possibly ongoing recognition of a confessor's standing in the post-Constantinian church. Moreover, Rufinus, Ps.-Gelasius, Socrates, and Sozomen construe Paphnutius of Egypt's suffering as an acknowledgment from, or of, the emperor Constantine.

42. Barnes, Constantine and Eusebius, 214 and 379 n. 52, referring to Rufinus, H. e. 10.4, 12; Socrates, H. e. 1.11.1ff.; Sozomen, H. e. 1.10, 23; Theodoret, H. e. 1.7.6, 2.26.6; Gelasius of Cyzicus, H. e. 2.9.

43. See above on Cameron and Hall, Eusebius, Life of Constantine, 263, who follow Barnes, Constantine and Eusebius, 214, on this point. Similarly MacMullen, Constantine, 172-73. 
Just as in later Christian literature martyrs could be hailed for their heavenly standing due to steadfastness amidst suffering, so could confessors on earth eventually be revered as comprising the "assembly of martyrs" gathered at Nicaea and recognized by none less than Constantine himself (Theodoret, H. e. 1.7.6).

James A. Kelhoffer is Professor of New Testament Exegesis at Uppsala University in Uppsala, Sweden 